\title{
Penile carcinoma and HPV infection (Review)
}

\author{
LUCIAN IORGA ${ }^{1}$, RADU DRAGOS MARCU ${ }^{1,2}$, CAMELIA CRISTINA DIACONU $^{2,3}$, \\ ANA MARIA ALEXANDRA STANESCU ${ }^{2}$, ANCA PANTEA STOIAN ${ }^{2}$, DAN LIVIU DOREL MISCHIANU ${ }^{1,2}$, \\ MIHAELA SURCEL $^{4}$, SIMONA BUNGAU ${ }^{5}$, TRAIAN CONSTANTIN ${ }^{2,6}$, DANIEL BODA ${ }^{7}$, \\ LASZLO FEKETE $^{8}$ and OVIDIU GABRIEL BRATU ${ }^{1,2}$ \\ ${ }^{1}$ Urology Department, Emergency University Central Military Hospital, 010825 Bucharest; \\ ${ }^{2 ،}$ Carol Davila' University of Medicine and Pharmacy, 050474 Bucharest; ${ }^{3}$ Internal Medicine Department, \\ Clinical Emergency Hospital of Bucharest, 014461 Bucharest; ${ }^{4}$ Immunology Department, \\ Victor Babes National Institute of Pathology, 050096 Bucharest; ${ }^{5}$ Department of Pharmacy, University of Oradea, \\ 410073 Oradea; ${ }^{6}$ Urology Department, 'Prof. Th Burghele' Clinical Hospital, 050652 Bucharest; \\ ${ }^{7}$ Dermatology Research Laboratory, 'Carol Davila' University of Medicine and Pharmacy, 050474 Bucharest; \\ ${ }^{8}$ Dermamed Private Clinic, 211 E60 Targu Mures, Romania
}

Received September 9, 2019; Accepted October 11, 2019

DOI: $10.3892 / \mathrm{etm} .2019 .8181$

\begin{abstract}
Penile carcinoma is a relatively frequent health issue in the developing countries such as Africa, Asia and South America, usually affecting men aged between 50 and 70 years. It is a highly treatable disease in its early stages, but has serious physical and psychological consequences. Usually, penile carcinoma is located in the penile glans, in approximately half the cases, with the most frequent histological type being squamous cell carcinoma with its microscopic subtypes. A large number of risk factors have been reported for this disease, having a multifactorial etiology, HPV infection being one of the most important factors involved in its appearance. Out of the HPV DNA positive genital cancers HPV-16 is the most frequently found type in men, followed by HPV-18. The evolution of penile cancer includes two independent carcinogenic pathways, related or unrelated to HPV infection. There is limited data available in literature regarding HPV-related neoplasia, as well as on the efficacy of vaccination in men, with studies still ongoing.
\end{abstract}

\section{Contents}

1. Introduction

2. HPV serotypes

3. HPV presence in genital lesions in men

Correspondence to: Professor Camelia Cristina Diaconu, 'Carol Davila' University of Medicine and Pharmacy, 8 Eroii Sanitari Street, 050474 Bucharest, Romania

E-mail: drcameliadiaconu@gmail.com

Key words: penile carcinoma, squamous cell carcinoma, HPV infection, risk factors, vaccination
4. HPV pathogenesis

5. Prevention of HPV infection in men

6. Conclusions

\section{Introduction}

Carcinoma of the penis is a rare neoplasm in industrialized countries, but the incidence of this malignancy is much higher in the developing countries of Africa, Asia and South America. For example, penile cancer accounts for $<1 \%$ of all malignancies in men in the United States, with 2,100 new cases and $\sim 400$ deaths annually (1). On the other hand, Brazil has the highest incidence with 2.8-6.8 per 100,000 men, with penile carcinoma being the fourth most common tumor in men $(2,3)$.

While penile carcinoma is found more often in men aged from 50 to 70 years, it is reported that any male can be affected (4). Highly treatable in its early stages, by means of radical penile and inguinal surgery, it usually caries important physical and psychosexual morbidity for the patients who undergo such procedures. However, with the development of organ-sparing surgery, the risk of significant physical and psychological consequences is significantly lower (5).

The glans are the most common site of penile carcinoma, accounting for up to $48 \%$ of cases, followed by the prepuce $(21 \%)$, glans and prepuce $(9 \%)$, coronal sulcus $(6 \%)$ and uncommonly the penile shaft $(<2 \%)(6)$. Squamous cell carcinoma (SCC) accounts for $\sim 95 \%$ of all penile cancer cases, followed by a wide range of other malignancies such as basal cell carcinoma, penile sarcomas, melanoma, lymphoma and metastatic disease. SCC can be classified by microscopic histologic findings into several subtypes: usual type of SCC (45-65\%), papillary carcinoma (2-15\%), Warty/ condylomatous tumors (7-10\%), basaloid carcinoma (4-10\%), verrucous carcinoma (3-7\%) and sarcomatoid (spindle cell) carcinoma $(1-6 \%)(7,8)$. 
Penile carcinoma has a multifactorial etiology, the most common risk factors being human papillomavirus (HPV) infection, phimosis and poor hygiene, as well as lack of circumcision, lichen sclerosis and inflammatory conditions (balanitis xerotica obliterans), premalignant lesions (Bowen's disease, erythroplasia Queyrat), compromised immune system, obesity, smoking, UVA phototherapy, increasing number of sexual partners and socioeconomic status.

HPV infection has been linked to penile carcinoma, the exact mechanism involved in its pathogenesis not being fully elucidated. HPV has been linked with other malignancies including cervical cancer, anal cancer and oropharyngeal cancer. More than $20 \%$ of patients with penile cancer have been tested positive for HPV infection, HPV prevalence depending on the method of sampling, processing methods and the anatomic sites or specimens sampled. The prevalence of HPV seems to be much higher in uncircumcised men compared to circumcised patients (9). HPV DNA is detected in up to $90 \%$ of cervical tumor cells and $\sim 68 \%$ of tonsillar tumor cells $(10,11)$.

\section{HPV serotypes}

Papillomaviruses are highly specific (they infect only humans), double-stranded DNA viruses that constitute the Papillomavirus genus of the Papillomaviridae family. There are more than 200 types of HPV, which can be subdivided, based on their tissue tropism, into cutaneous or mucosal categories. Human papillomaviruses (HPVs) are small, nonenveloped viruses with a circular genome that encodes eight genes and a replication cycle integrally linked to epithelial differentiation.

There are 20 types of HPV which are known to infect the genital tract and they are classified as 'high-risk' and 'low-risk' depending on the probability to cause cancer. A study found fifteen HPV types which were classified as high risk: 16, 18, $31,33,35,39,45,51,52,56,58,59,68,73$ and 82 , with HPV-16 having the highest risk of progressing to cancer (10). Type 6 and 11 were found in benign lesions, therefore they were classified as low-risk subtypes.

In a study on human papillomavirus genotype attribution in invasive cervical cancer, the authors examined 10,575 paraffin-embedded samples and found that HPV types 16 and 18 represented $71 \%$ of all cases (11). Wiener and his colleagues, in their study on the prevalence of human papillomavirus types 16 and 18 in squamous cell carcinoma of the penis, found that these subtypes were implicated in $31 \%$ of cases, with HPV-16 being the predominant type (12).

It has been observed that HPV subtypes influence the rate of progression from infection to disease. In this light, Ingles et al (13) showed that 22\% of HPV-11 infections developed into HPV-11 condyloma compared with only $16 \%$ of HPV-6 infections developing into specific condylomas, with a median time of 7.7 months. Furthermore, Sudenga et al (14) noted that only $2 \%$ of HPV-16 infections developed into PeIN, within a 2 year period.

\section{HPV presence in genital lesions in men}

Genitourinary HPV infections in men results in a wide spectrum of pathologies, ranging from genital warts, to penile intraepithelial neoplasia (PeIN) and penile carcinoma. Infection with oncogenic subtypes of HPV, such as HPV-16 and HPV-18, appears to be mandatory for the development of cervical cancer. Although, it appears that all cervical cancers are due to HPV infections, only a small fraction of penile carcinomas are caused by HPV. This observation has led to the assumption that penile tissue has an increased resistance to malignant transformation compared with cervical tissue. Most HPV infections do not develop into external lesions and remain asymptomatic, being immunologically cleared within 1 year $(9,15)$. Giuliano et al (16), in their cohort study on human papillomavirus infection in men (HIM) found that the median time to clearance of infection was 7.5 months, with a longer clearance time (12.2 months) for HPV-16 subtype. When the infection is not cleared, it usually develops into genital warts (condyloma acuminata), resulting from the production of virus in the squamous epithelium, a benign lesion, commonly asymptomatic, but can be problematic, causing pain, itching and bleeding.

PeIN is a viral-associated preneoplastic lesion, resulting from the integration of viral genome into the DNA of the host cell, leading to oncogene overexpression and cell proliferation (17). PeIN lesions are classified as differentiated, resulting from non-viral factors such as inflammation, lichen sclerosis, phimosis, usually progressing to well-differentiated and keratinized SCC and undifferentiated, associated with HPV infections and expected to develop into basaloid and warty subtypes of SCC $(18,19)$.

PeIN is classified into grade I, grade II and grade III, similar to the system used for cervical intraepithelial neoplasia, and it includes Erythroplasia of Queyrat (erythematous plaque on the glans and prepuce) and Bowen's disease (scaly hyperkeratotic plaque, usually on shaft of penis). Erythropasia of Queyrat has the highest risk of progressing to SCC.

In a study on the role of HPV in penile carcinoma conducted by Alemany et al (20) it was found that out of the 85 diagnosed precancerous lesions, $87 \%$ were positive for HPV DNA and that only $33 \%$ of penile carcinomas were HPV related. In another study up to $90 \%$ of PeIN lesions were positive for HPV DNA, with HPV-16 being the most common subtype (21). Regarding the relationship between HPV prevalence and the degree of dysplasia, Aynaud et al (22) found that $75 \%$ of grade I PeIN, 93\% of grade II PeIN, and respectively, $100 \%$ of grade III PeIN were positive for HPV DNA.

HPV detection in penile carcinomas is very inconsistent, compared to cervical cancers, in which HPV infection is present in nearly all cases. Some studies found that HPV prevalence in penile cancers is $\sim 46-48 \%$, with HPV-16 and 18 representing the most common types $(23,24)$. HPV seems to vary among the many histological SCC subtypes. The more keratinized the subtype, such as the usual and verrucous SCC, the less risk of HPV positivity. The highest HPV detection was found in the warty and basaloid subtypes of SCC. Backes et al (23) detected HPV in only $22.4 \%$ of the verrucous SCC cases, but it was present in $66.3 \%$ of the basaloid/warty subtypes.

The high heterogenity regarding the presence of HPV in penile cancers had some authors consider HPV presence as a prognostic marker for survival. In HPV related oropharyngeal and anal cancers studies found that HPV association may 
result in improved survival $(25,26)$. Lont et al (27) evaluated 176 patients regarding HPV prevalence and their survival rate and found that $29 \%$ of cases had high-risk HPV infection and was associated with a better 5-year survival rate compared with HPV-negative patients (92 vs. 78\%). Another group studied 212 formalin fixed, paraffin embedded invasive penile tumor specimens of patients treated between 2001 and 2009 and found similar results, with a better 5 -year disease specific survival in the high risk HPV positive group (96 vs. $86 \%$ in the HPV negative group) (28). However, some studies have failed to show similar results in terms of survival rate. Furthermore, Lopes et al (29), in their study evaluating p53 status as a prognostic factor, found that patients positive for $\mathrm{p} 53$ and HPV DNA had worse overall survival. A better understanding of HPV related carcinogenesis can improve our understanding of HPV infection as a prognostic marker.

\section{HPV pathogenesis}

Unlike cervical squamous cancer, in which the pathogenesis of HPV-related neoplasia is well known, the carcinogenesis of penile carcinoma is not well understood. HPV related penile cancer has been associated with warty and basaloid subtypes of SCC. Gross and Pfister (30), found HPV DNA in $100 \%$ of the warty subtypes and in $80 \%$ of the basaloid forms. On the other hand, keratinizing and verrucous subtypes had the lowest percentage of HPV DNA, $34.9 \%$ and $33.3 \%$, respectively.

HPV affects the epithelium in two ways, either as a viral infection, in which the squamous epithelium supports the virion production, developing into low-grade lesions such as condylomas, or as a viral-associated precancerous lesion, that occurs when the viral genome is included into the DNA of the host cell, this leading to the overexpression of the oncogenes, which leads to uncontrolled cell proliferation.

Of the eight genes encoded into the viral DNA three important oncogenes are included: E5, E6 and E7. E5 oncoprotein is not necessary for malignant transformation, though its activation may contribute to carcinogenesis through manipulating viral uptake of host cells. Furthermore, E5 gene product regulates the activation of epidermal growth factor receptor (EGFR) and this will lead to a decrease of E-cadherin expression, which will furthermore favor (in a combination with other factors) the reduction of cell-to-cell adhesion. At the opposite end of the spectrum, E6 and E7 oncogenes, which are actively transcribed into the infected cells, are essential for viral-induced malignant transformation. These genes disrupt the centrosome synthesis, a vital component of cell division, with the development of multipolar cell divisions. Moreover, E6 targets p53 tumor suppressor protein, while E7 targets retinoblastoma-1 tumor suppressor protein, two negative regulators of cellular proliferation, whose inactivation leads to uncontrolled cellular proliferation $(18,31,32)$. Some studies found that in HPV-16 induced tonsillar cancer, E6 and E7 genes are usually expressed $(33,34)$.

Aditionally, E7 oncoprotein has been observed to have a higher affinity for retinoblastoma-1 tumor suppressor protein in high-risk HPV than in the low-risk subtypes. E7 activity on retinoblastoma-1 tumor suppressor blocks the feedback inhibition on p16ink4a, a cyclin-dependent kinase inhibitor, resulting in an increased expression of p16ink4a and its accumulation in the nucleus. A study on 53 patients with penile cancer in which 15 cases were HPV-16 induced neoplasia, found E6 and E7 transcripts in 13 patients. Immunostaining for p16ink4a showed that 12 out of the 13 patients had strong nuclear and cytoplasmic staining. This strong relationship between HPV infection and the high levels of intranuclear and intracytoplasmatic p16ink4a resulted in the use of this cyclin-dependent kinase inhibitor as an immunohistochemical marker $(35,36)$.

\section{Prevention of HPV infection in men}

Preventing HPV infection is the only way to reduce HPV-related diseases, as there is no known treatment. A series of preventive measures have been proposed to minimize the risk of contracting the disease. Limiting sexual partners and condom use have been listed as methods of reducing HPV transmission (37-41).

A matter highly debatable is the presence or absence of circumcision as a preventive measure for HPV infection. A systematic review of the relationship between circumcision and human papillomavirus infection found circumcised men, compared with men who were not circumcised, had significantly reduced odds of genital HPV prevalence, with no significant association between these two groups regarding new infections, or clearance (42). It is still unclear if circumcision represents a protective measure against HPV infection. A report of three patients who underwent neonatal circumcision and later developed penile carcinoma suggested that the oncogenic potential of HPV remains despite neonatal circumcision. All three had a history of penile condyloma, and in one case oncogenic HPV had been detected in the tumor (43). Similar results were shown by other studies, with no difference in incidence between uncircumcised and circumcised men and with no protection against HPV infection (44-46). However, some studies have shown a protective effect in comparison with a control group. A randomized control trial found that high-risk HPV subtype prevalence among circumcised and uncircumcised men were 14.8 and $22.3 \%$, respectively (47). Similarly, Tobian et al (48) found that the prevalence of high-risk HPV genotypes was $18.0 \%$ in the circumcised group and $27.9 \%$ in the uncircumcised group.

Although several preventive measures have been proposed, the best method of reducing HPV infection remains vaccination. The first ever vaccine approved by the FDA was Gardasil and consisted of a quadrivalent strain, covering HPV-6, 11, 16 and 18 , in 2006. This was followed by the bivalent vaccine (Cervarix) in 2009 covering HPV-18 and HPV-16 in 2014, FDA approved the 9-valent version of Gardasil for HPV types $6,11,16,18,31,33,45,52$ and 58 . The majority of the published papers on HPV vaccination focus on cervical intraepithelial neoplasia and cervical cancer and less on male HPV cases. It is concerning that men have a low rate of seroconversion after natural infection and that HPV antibody seropositivity does not provide significant immunity to future infection as it does in women $(49,50)$. However, a study that focused on the immunogenicity of the quadrivalent human papillomavirus vaccine found that it is highly efficient in men aged from 16 to 26 years, with seroconversion within 7 months, with antibodies being detected even at 36 months, 
numbers comparable with those encountered in clinical trials conducted in female patients (51). In a study conducted by Giuliano et al (52) similar results regarding the efficacy of the quadrivalent HPV vaccine against HPV infection in male patients were found (53-61).

A systematic review regarding the efficacy, the effectiveness and the safety of vaccination against human papillomavirus in male patients concluded that vaccine effectiveness was low in individuals who are already infected with the corresponding HPV type, but was high in study groups comprising HPV-negative males, supporting a recommendation for early vaccination of boys with the goal of vaccine-induced protection before the onset of sexual activity (62).

Vaccine schedule includes a single dose, followed by a second dose 1-2 months later and afterwards a final dose 6 months later (63-68). Current recommendation regarding male vaccination from CDC Advisory Committee on Immunization Practices are as follows: routine male vaccination beginning at the age of 11 or 12 years with either the quadrivalent or 9-valent vaccine, also vaccination for males aged between 13 and 21, who have not completed a three-dose cycle. Men aged between 22 and 26 may be vaccinated as well, particularly those men who engage in sexual activity with members of the same sex and those who are immunocompromised (69-71). The European Association of Urology guidelines do not recommend vaccination as a method for reducing the risk of penile cancer.

\section{Conclusions}

Penile cancer is a frequent health issue in developing countries with HPV being a known risk factor for its development. High-risk subtypes of HPV have been found in up to $40 \%$ of cases, the highest detection rates are in the warty and basaloid subtypes of SCC. A better understanding of the HPV-related carcinogenesis holds the potential for future prognostic markers and a targeted treatment. There is no current treatment for HPV infection, except for the treatment of cutaneous lesions, so prevention methods and an increase of patient education are of great importance. Despite the fact that the promotion of HPV vaccination in women has led to some success regarding HPV-related cancers, the results are yet to be elucidated in the male population.

\section{Acknowledgements}

Not applicable.

\section{Funding}

No funding was received.

\section{Availability of data and materials}

Not applicable.

\section{Authors' contributions}

LI, RDM, CCD, TC, DB, LF and AMAS collected, analyzed and interpreted the patient data regarding penile carcinoma and HPV infection. CCD, APS, DLDM, MS, SB and OGB made substantial contributions to the conception of the study and the interpretation of data; also, they drafted the manuscript and were major contributors in writing the manuscript. All authors read and approved the final manuscript.

\section{Ethics approval and consent to participate}

Not applicable.

\section{Patient consent for publication}

Not applicable.

\section{Competing interests}

The authors declare that they have no competing interests.

\section{References}

1. Siegel RL, Miller KD and Jemal A: Cancer statistics, 2019. CA Cancer J Clin 69: 7-34, 2019.

2. Favorito LA, Nardi AC, Ronalsa M, Zequi SC, Sampaio FJ and Glina S: Epidemiologic study on penile cancer in Brazil. Int Braz J Urol 34: 587-593, 2008.

3. Couto TC,ArrudaRM,Couto MC and Barros FD: Epidemiological study of penile cancer in Pernambuco: Experience of two reference centers. Int Braz J Urol 40: 738-744, 2014.

4. Pow-Sang MR, Ferreira U, Pow-Sang JM, Nardi AC and Destefano V: Epidemiology and natural history of penile cancer. Urology 76 (Suppl 1): S2-S6, 2010.

5. Misra S, Chaturvedi A and Misra NC: Penile carcinoma: A challenge for the developing world. Lancet Oncol 5: 240-247, 2004.

6. Mosconi AM, Roila F, Gatta G and Theodore C: Cancer of the penis. Crit Rev Oncol Hematol 53: 165-177, 2005.

7. Cubilla AL, Dillner J and Schellhammer PF: Tumours of the penis. In: Tumors of the Urinary System and Mail Genital Organs. Eble JN, Sauter G and Epstein JI (eds). World Health Organization, Lyon, p279, 2010.

8. Sanchez DF, Soares F, Alvarado-Cabrero I, Cañete S, FernándezNestosa MJ, Rodríguez IM, Barreto J and Cubilla AL: Pathological factors, behavior, and histological prognostic risk groups in subtypes of penile squamous cell carcinomas (SCC). Semin Diagn Pathol 32: 222-231, 2015.

9. Dunne EF,Nielson CM,Stone KM,MarkowitzLE and Giuliano AR: Prevalence of HPV infection among men: A systematic review of the literature. J Infect Dis 194: 1044-1057, 2006.

10. Muñoz N, Bosch FX, de Sanjosé S, Herrero R, Castellsagué X, Shah KV, Snijders PJ and Meijer CJ; International Agency for Research on Cancer Multicenter Cervical Cancer Study Group: Epidemiologic classification of human papillomavirus types associated with cervical cancer. N Engl J Med 348: 518-527, 2003.

11. Hammarstedt L, Lindquist D, Dahlstrand H, Romanitan M, Dahlgren LO, Joneberg J, Creson N, Lindholm J, Ye W, Dalianis T, et al: Human papillomavirus as a risk factor for the increase in incidence of tonsillar cancer. Int J Cancer 119: 2620-2623, 2006.

12. Wiener JS, Effert PJ, Humphrey PA, Yu L, Liu ET and Walther PJ: Prevalence of human papillomavirus types 16 and 18 in squamous-cell carcinoma of the penis: A retrospective analysis of primary and metastatic lesions by differential polymerase chain reaction. Int J Cancer 50: 694-701, 1992.

13. Ingles DJ, Pierce Campbell CM, Messina JA, Stoler MH, Lin HY, Fulp WJ, Abrahamsen M, Sirak BA, O'Keefe MT, Papenfuss M, et al: Human papillomavirus virus (HPV) genotype- and age-specific analyses of external genital lesions among men in the HPV Infection in Men (HIM) Study. J Infect Dis 211: 1060-1067, 2015.

14. Sudenga SL, Ingles DJ, Pierce Campbell CM, Lin HY, Fulp WJ, Messina JL, Stoler MH, Abrahamsen M, Villa LL, Lazcano-Ponce E, et al: Genital human papillomavirus infection progression to external genital lesions: The HIM Study. Eur Urol 69: 166-173, 2016. 
15. Lu B, Wu Y, Nielson CM, Flores R, Abrahamsen M,Papenfuss M, Harris RB and Giuliano AR: Factors associated with acquisition and clearance of human papillomavirus infection in a cohort of US men: A prospective study. J Infect Dis 199: 362-371, 2009.

16. Giuliano AR, Lee J-H, Fulp W, Villa LL, Lazcano E, Papenfuss MR, Abrahamsen M, Salmeron J, Anic GM, Rollison DE, et al: Incidence and clearance of genital human papillomavirus infection in men (HIM): A cohort study. Lancet 377: 932-940, 2011.

17. Spiess PE, Dhillon J, Baumgarten AS, Johnstone PA and Giuliano AR: Pathophysiological basis of human papillomavirus in penile cancer: Key to prevention and delivery of more effective therapies. CA Cancer J Clin 66: 481-495, 2016.

18. Chaux A, Velazquez EF, Algaba F, Ayala G and Cubilla AL: Developments in the pathology of penile squamous cell carcinomas. Urology 76 (Suppl 1): S7-S14, 2010.

19. Gregoire L, Cubilla AL, Reuter VE, Haas GP and Lancaster WD: Preferential association of human papillomavirus with high-grade histologic variants of penile-invasive squamous cell carcinoma. J Natl Cancer Inst 87: 1705-1709, 1995.

20. Alemany L, Cubilla A, Halec G, Kasamatsu E, Quirós B, Masferrer E, Tous S, Lloveras B, Hernández-Suarez G, Lonsdale R, et al; HPV VVAP study group: Role of human papillomavirus in penile carcinomas worldwide. Eur Urol 69: 953-961, 2016

21. Rubin MA, Kleter B, Zhou M, Ayala G, Cubilla AL, Quint WG and Pirog EC: Detection and typing of human papillomavirus DNA in penile carcinoma: Evidence for multiple independent pathways of penile carcinogenesis. Am J Pathol 159: 1211-1218, 2001.

22. Aynaud O, Ionesco M and Barrasso R: Penile intraepithelial neoplasia. Specific clinical features correlate with histologic and virologic findings. Cancer 74: 1762-1767, 1994.

23. Backes DM, Kurman RJ, Pimenta JM and Smith JS: Systematic review of human papillomavirus prevalence in invasive penile cancer. Cancer Causes Control 20: 449-457, 2009

24. Miralles-Guri C, Bruni L, Cubilla AL, Castellsagué X, Bosch FX and de Sanjosé S: Human papillomavirus prevalence and type distribution in penile carcinoma. J Clin Pathol 62: 870-878, 2009

25. Ang KK, Harris J, Wheeler R, Weber R, Rosenthal DI, Nguyen-Tân PF, Westra WH, Chung CH, Jordan RC, Lu C, et al: Human papillomavirus and survival of patients with oropharyngeal cancer. N Engl J Med 363: 24-35, 2010.

26. Serup-Hansen E, Linnemann D, Skovrider-Ruminski W, Høgdall E, Geertsen PF and Havsteen H: Human papillomavirus genotyping and p16 expression as prognostic factors for patients with American Joint Committee on Cancer stages I to III carcinoma of the anal canal. J Clin Oncol 32: 1812-1817, 2014.

27. Lont AP, Kroon BK, Horenblas S, Gallee MP, Berkhof J, Meijer CJ and Snijders PJ: Presence of high-risk human papillomavirus DNA in penile carcinoma predicts favorable outcome in survival. Int J Cancer 119: 1078-1081, 2006.

28. Djajadiningrat RS, Jordanova ES, Kroon BK, van Werkhoven E, de Jong J, Pronk DT, Snijders PJ, Horenblas S and Heideman DA: Human papillomavirus prevalence in invasive penile cancer and association with clinical outcome. J Urol 193: 526-531, 2015.

29. Lopes A, Bezerra ALR, Pinto CAL, Serrano SV, de Mello CA and Villa LL: p53 as a new prognostic factor for lymph node metastasis in penile carcinoma: Analysis of 82 patients treated with amputation and bilateral lymphadenectomy. J Urol 168 : 81-86, 2002

30. Gross G and Pfister H: Role of human papillomavirus in penile cancer, penile intraepithelial squamous cell neoplasias and in genital warts. Med Microbiol Immunol (Berl) 193: 35-44, 2004.

31. Agarwal G, Gupta S and Spiess PE: Novel targeted therapies for the treatment of penile cancer. Expert Opin Drug Discov 9: 959-968, 2014

32. Flaherty A, Kim T, Giuliano A, Magliocco A, Hakky TS, Pagliaro LC and Spiess PE: Implications for human papillomavirus in penile cancer. Urol Oncol 32: 53.e1-8, 2014.

33. Snijders PJ, Cromme FV, van den Brule AJ, Schrijnemakers HF, Snow GB, Meijer CJ and Walboomers JM: Prevalence and expression of human papillomavirus in tonsillar carcinomas, indicating a possible viral etiology. Int J Cancer 51: 845-850, 1992.

34. Wilczynski SP, Lin BT, Xie Y and Paz IB: Detection of human papillomavirus DNA and oncoprotein overexpression are associated with distinct morphological patterns of tonsillar squamous cell carcinoma. Am J Pathol 152: 145-156, 1998.
35. Ferreux E, Lont AP, Horenblas S, Gallee MP, Raaphorst FM, von Knebel Doeberitz M, Meijer CJ and Snijders PJ: Evidence for at least three alternative mechanisms targeting the $\mathrm{p} 16 \mathrm{INK} 4 \mathrm{~A} /$ cyclin $\mathrm{D} / \mathrm{Rb}$ pathway in penile carcinoma, one of which is mediated by high-risk human papillomavirus. J Pathol 201: $109-118,2003$

36. Cubilla AL, Lloveras B, Alejo M, Clavero O, Chaux A, Kasamatsu E, Monfulleda N, Tous S, Alemany L, Klaustermeier J, et al: Value of p16(INK)4(a) in the pathology of invasive penile squamous cell carcinomas: A report of 202 cases. Am J Surg Pathol 35: 253-261, 2011.

37. Beder Ribeiro CM, Ferrer I, Santos de Farias AB, Fonseca DD, Morais Silva IH, Monteiro Gueiros LA, Carvalho AT, Porter SR and Leao JC: Oral and genital HPV genotypic concordance between sexual partners. Clin Oral Investig 18: 261-268, 2014.

38. Deshmukh AA, Tanner RJ, Luetke MC, Hong YR, Sonawane Deshmukh K and Mainous AG III: Prevalence and risk of penile human papillomavirus infection: Evidence from the national health and nutrition examination survey 2013-2014. Clin Infect Dis 64: 1360-1366, 2017.

39. Anic GM, Lee JH, Villa LL, Lazcano-Ponce E, Gage C, José C Silva R, Baggio ML, Quiterio M, Salmerón J, Papenfuss MR, et al: Risk factors for incident condyloma in a multinational cohort of men: The HIM study. J Infect Dis 205: 789-793, 2012.

40. Vardas E, Giuliano AR, Goldstone S, Palefsky JM, Moreira ED Jr, Penny ME, Aranda C, Jessen H, Moi H, Ferris DG, et al: External genital human papillomavirus prevalence and associated factors among heterosexual men on 5 continents. J Infect Dis 203: 58-65, 2011.

41. Winer RL, Hughes JP, Feng Q, O'Reilly S, Kiviat NB, Holmes KK and Koutsky LA: Condom use and the risk of genital human papillomavirus infection in young women. N Engl J Med 354: 2645-2654, 2006.

42. Zhu YP, Jia ZW, Dai B, Ye DW, Kong YY, Chang K and Wang Y: Relationship between circumcision and human papillomavirus infection: A systematic review and meta-analysis. Asian J Androl 19: 125-131, 2017.

43. Saibishkumar EP, Crook J and Sweet J: Neonatal circumcision and invasive squamous cell carcinoma of the penis: A report of 3 cases and a review of the literature. Can Urol Assoc J 2: 39-42, 2008.

44. Albero G, Castellsagué X, Lin H-Y, Fulp W, Villa LL, Lazcano-Ponce E, Papenfuss M, Abrahamsen M, Salmerón J, Quiterio M, et al: Male circumcision and the incidence and clearance of genital human papillomavirus (HPV) infection in men: The HPV Infection in men (HIM) cohort study. BMC Infect Dis 14: 75, 2014.

45. Weaver BA, Feng Q, Holmes KK, Kiviat N, Lee SK, Meyer C, Stern $M$ and Koutsky LA: Evaluation of genital sites and sampling techniques for detection of human papillomavirus DNA in men. J Infect Dis 189: 677-685, 2004.

46. Boda D, Neagu M, Constantin C, Voinescu RN, Caruntu C, Zurac S, Spandidos DA, Drakoulis N, Tsoukalas D and Tsatsakis AM: HPV strain distribution in patients with genital warts in a female population sample. Oncol Lett 12: 1779-1782, 2016.

47. Auvert B, Sobngwi-Tambekou J, Cutler E, Nieuwoudt M, Lissouba P, Puren A and Taljaard D: Effect of male circumcision on the prevalence of high-risk human papillomavirus in young men: Results of a randomized controlled trial conducted in Orange Farm, South Africa. J Infect Dis 199: 14-19, 2009.

48. Tobian AAR, Serwadda D, Quinn TC, Kigozi G, Gravitt PE, Laeyendecker O, Charvat B, Ssempijja V, Riedesel M, Oliver AE, et al: Male circumcision for the prevention of HSV-2 and HPV infections and syphilis. N Engl J Med 360: 1298-1309, 2009.

49. Giuliano AR, Viscidi R, Torres BN, Ingles DJ, Sudenga SL, Villa LL, Baggio ML, Abrahamsen M, Quiterio M, Salmeron J, et al: Seroconversion following anal and genital HPV infection in men: The HIM Study. Papillomavirus Res 1: 109-115, 2015.

50. $\mathrm{Lu} \mathrm{B}$, Viscidi RP, Wu Y, Lee JH, Nyitray AG, Villa LL, Lazcano-Ponce E, da Silva RJ, Baggio ML, Quiterio M, et al: Prevalent serum antibody is not a marker of immune protection against acquisition of oncogenic HPV16 in men. Cancer Res 72: 676-685, 2012

51. Hillman RJ, Giuliano AR, Palefsky JM, Goldstone S, Moreira ED Jr, Vardas E, Aranda C, Jessen H, Ferris DG, Coutlee $\mathrm{F}$, et al: Immunogenicity of the quadrivalent human papillomavirus (type 6/11/16/18) vaccine in males 16 to 26 years old. Clin Vaccine Immunol 19: 261-267, 2012. 
52. Giuliano AR, Palefsky JM, Goldstone S, Moreira ED Jr, Penny ME, Aranda C, Vardas E, Moi H, Jessen H, Hillman R, et al: Efficacy of quadrivalent HPV vaccine against HPV infection and disease in males. N Engl J Med 364: 401-411, 2011.

53. Ghita MA, Caruntu C, Rosca AE, Kaleshi H, Caruntu A, Moraru L, Docea AO, Zurac S, Boda D, Neagu M, et al: Reflectance confocal microscopy and dermoscopy for in vivo, non-invasive skin imaging of superficial basal cell carcinoma. Oncol Lett 11: 3019-3024, 2016.

54. Diaconeasa A, Boda D, Solovan C, Enescu DM, Vîlcea AM and Zurac S: Histopathologic features of Spitzoid lesions in different age groups. Rom J Morphol Embryol 54: 51-62, 2013.

55. Căruntu C, Boda D, Gutu DE and Căruntu A: In vivo reflectance confocal microscopy of basal cell carcinoma with cystic degeneration. Rom J Morphol Embryol 55: 1437-1441, 2014.

56. Lupu M, Caruntu A, Caruntu C, Boda D, Moraru L, Voiculescu V and Bastian A: Non-invasive imaging of actinic cheilitis and squamous cell carcinoma of the lip. Mol Clin Oncol 8: 640-646, 2018.

57. Ianoși SL, Batani A, Ilie MA, Tampa M, Georgescu SR, Zurac S, Boda D, Ianosi NG, Neagoe D, Calina D, et al: Non-invasive imaging techniques for the in vivo diagnosis of Bowen's disease: Three case reports. Oncol Lett 17: 4094-4101, 2019.

58. Lupu M, Caruntu C, Popa MI, Voiculescu VM, Zurac S and Boda D: Vascular patterns in basal cell carcinoma: Dermoscopic confocal and histopathological perspectives. Oncol Lett 17: 4112-4125, 2019.

59. Cioplea M, Caruntu C,Zurac S, Bastian A, Sticlaru L, Cioroianu A, Boda D, Jugulete G, Nichita L and Popp C: Dendritic cell distribution in mycosis fungoides vs. inflammatory dermatosis and other T-cell skin lymphoma. Oncol Lett 17: 4055-4059, 2019.

60. Ilie MA, Caruntu C, Lupu M, Lixandru D, Tampa M, Georgescu SR, Bastian A, Constantin C, Neagu M, Zurac SA, et al: Current and future applications of confocal laser scanning microscopy imaging in skin oncology. Oncol Lett 17: 4102-4111, 2019.

61. Ianoși SL, Forsea AM, Lupu M, Ilie MA, Zurac S, Boda D, Ianosi G, Neagoe D, Tutunaru C, Popa CM, et al: Role of modern imaging techniques for the in vivo diagnosis of lichen planus. Exp Ther Med 17: 1052-1060, 2019.

62. Harder T, Wichmann O, Klug SJ, van der Sande MA and Wiese-Posselt M: Efficacy, effectiveness and safety of vaccination against human papillomavirus in males: A systematic review. BMC Med 16: 110, 2018.
63. Socea LI, Visan DC, Barbuceanu SF, Apostol TV, Bratu OG and Socea B: The antioxidant activity of some acylhydrazones with dibenzo[a,d][7] annulene moiety. Rev Chim Buchar 69: 795-797, 2018.

64. Spinu D, Bratu O, Marcu D, Mischianu D, Huica R, Surcel M, Munteanu A, Socea B, Bodean O and Ursaciuc C: The use of ELISA and PCR in identifying correlations between viral infections and benign prostatic hypertrophy. Rev Chim Buchar 69: 645-649, 2018.

65. Radulescu A, Madan V, Aungurenci A, Bratu O, Farcas C, Dinu $\mathrm{M}$ and Mischianu D: Antibiotic resistant urinary tract infections in an urology ward. Rom J Mil Med 118: 20-22, 2015.

66. Spinu D, Bratu O, Marcu D, Niculae A, Geavlete B, Diaconu C and Mischianu D: HPV and bladder cancer - is there a connection? Mod Med 24: 1-4, 2017.

67. Spinu D, Mischianu D, Bratu O, Aungurenci A, Manache S and Ciuca A: HPV implications in benign prostatic impairments -a literature review. Mod Med 21: 298-303, 2014.

68. Spinu D, Bratu O, Popescu R, Marcu D, Radulescu A and Mischianu D: Clostridium difficile - an emerging plague. Rom J Mil Med 118: 12-15, 2015.

69. Markowitz LE, Dunne EF, Saraiya M, Chesson HW, Curtis CR, Gee J, Bocchini JA Jr and Unger ER; Centers for Disease Control and Prevention (CDC): Human papillomavirus vaccination: Recommendations of the Advisory Committee on Immunization Practices (ACIP). MMWR Recomm Rep 63: 1-30, 2014.

70. Petrosky E, Bocchini JA Jr, Hariri S, Chesson H, Curtis CR, Saraiya M, Unger ER and Markowitz LE; Centers for Disease Control and Prevention (CDC): Use of 9-valent human papillomavirus (HPV) vaccine: Updated HPV vaccination recommendations of the advisory committee on immunization practices. MMWR Morb Mortal Wkly Rep 64: 300-304, 2015.

71. Boda D, Docea AO, Calina D, Ilie MA, Caruntu C, Zurac S, Neagu M, Constantin C, Branisteanu DE, Voiculescu V, et al: Human papilloma virus: Apprehending the link with carcinogenesis and unveiling new research avenues (Review). Int J Oncol 52: 637-655, 2018. 